\title{
SOME RECENT RECORDS OF ALBERTA MAMMALS ${ }^{1}$
}

by Hugh C. Smith, Provincial Museum and Archives of Alberta, Edmonton

The following records are of some of the lesser known Alberta mammals. The scarcity of these animals in Alberta or the difficulty in trapping them has made the delineation of their range rather vague.

\section{WATER SHREW (Sorex palustris)}

A specimen of a water shrew was forwarded to the Provincial Museum and Archives of Alberta by Dr. R. T. Worsley of Bashaw, Alberta. This specimen was captured on June 14, 1971 in the hospital at Bashaw. Because of the poor state of preservation no measurements were made, but the specimen is retained as a formalin specimen (Museum number Z71.46.1).

The range of the water shrew in Alberta, as outlined by Soper (1964), is along the mountains in the southwest, and north from a line just south of Edmonton to Lloydminster. This record from Bashaw represents a range extension of approximately 30 miles south and 60 miles east of the present known range.

\section{KANGAROO RAT (Dipodomys ordii)}

During the summer of 1971 Provincial Museum and Archives of Alberta staff found further evidence of this rodent on the south side of the South Saskatchewan River in Township 19, Range 2, West 4. Burrows were in sand barks along a prairie trail. As well, the tip of the tail of a kangaroo rat was found in a trap set at one of these burrows.

The occurrence of the kangaroo rat in this part of Alberta was well established (Smith and Hampson, 1969).

\section{RACCOCN (Procyon lotor)}

In Alberta, raccoons are "rather rare and erratic" in their occurrence, but may be expected south of the Battle River and east of the foothills (Soper, 1964).

The following records are of interest

${ }^{1}$ Natural History Contribution Number 9 of the Provincial Museum and Archives of Alberta. in that four of them are outside this range:

April 1960. The Hudson's Bay Raw Fur department reported buying a large raccoon that had been trapped approximately 30 miles west of Edmonton, Alberta.

On April 25, 1961, the Medicine Hat News reported a raccoon caught in a beaver trap on the Ramsay Ranch 25 miles south of Walsh, Alberta.

On October 9, 1965, a raccoon was killed by a motor vehicle north and east of Clive, Alberta.

October, 1971. A male raccoon was shot at Bremner, Alberta. This animal weighed 21 pounds 11 ounces. The following measurements were taken: Length $970 \mathrm{~mm}$., tail $234 \mathrm{~mm}$., hind foot $122 \mathrm{~mm}$., ear (from notch) 65 $\mathrm{mm}$. The skeleton (Museum number 272.1.1) has been placed in the collections of the PMAA. Also in October 1971 a male raccoon was killed by a motor vehicle 45 miles north of Edmonton near Vimy, Alberta. The weight of this animal was approximately 21 pounds but because of its condition no measurements are available. However, the skin was salvaged and is in the PMAA collections as Museum number 271.91.1.

(I would like to thank W. Wishart, Research Biologist, Fish and Wildlife Branch, Department of Lands and Foresits of Alberta for providing me with the first three of these raccoon records.)

\section{WOLVERINE (Gulo luscus)}

The reporting of sight records is a dubious practice. However, because of the paucity of records of the wolverine from southern Alberta, the following is submitted with due caution regarding validity.

On July 7, 1970 at Bovin Lake ( $\mathrm{S}$ 19, T 3, R 1, W5) a wolverine was seen near the lake. This was reported to me by four students working for a geological survey party. They stated that when they rounded a bend in the road they saw the wolverine standing 
near the lake shore. As they approached the lake it retreated up a mountain path.

The only other record of a wolverine in southern Alberta is that reported by Scotter (1964) for Cardston. Soper (1964) gives Banff as the southern limit of its range and Banfield (1950) does not include the wolverine in his survey of Waterton Lakes National Park.

\section{LITERATURE CITED}

Banfield, A W. F. 1950. The mammals of Waterton Lakes National Park. Canadian Wildlife Service, Wildlife Management Bulletin. Ser. 1, No. 1:54.

Scotter, G. W. 1964. Occurrence of a wolverine in southwestern Alberta. Journal of Mammalogy, $45: 629$.

Smith, H. C. and M. J. Hampson, 1969. A kangaroo rat colony in Alberta. Blue Jay, $27: 224$.

Soper, J. D. 1964. The mammals of Alberta. The Department of Industry and Development Queen's Printer, Edmonton.

\section{AN OBSERVATION OF APPARENT DEATH-FEIGNING BY A TOAD ${ }^{1}$}

\section{by Martin K. McNicholl, Department of Zoology, University of Manitoba, Winnipeg ${ }^{2}$}

On July 5, 1970, while paddling a canoe along a ditch in the Delta Marsh, I noticed a small Canadian Toad (Bufo hemiophrys) swimming slowly alongside. I stopped and backed towards the toad, whereupon it swam rapidly for about eight inches and then suddenly flipped over, belly up, with hind-legs folded and fore-legs stretched beyond the head, as if feigning death (Fig. 1). Although I had seen hundreds of toads in the Marsh, none had ever before done this. Usually when encountered, toads either "froze", that is, remained belly down in the water with limbs extended or folded in the position in which they were encountered, or dived. In this case, the toad remained in the "dead" position for about 30 seconds, then righted itself and swam normally. When I again approached the toad, it this time "froze" and then began swimming rapidly. When further pursued, it dived, re-emerged about six inches away, and again "froze". I then picked it up to record its size. After being replaced in the water and again pursued, the toad flipped over onto its back and assumed the same posture described above. Additional attempts to elicit this behaviour, however, were unsuccessful.

\footnotetext{
1 Publication No. 15, University of Manitoba Field Station, Delta, Manitoba.

2 Present address: Department of Zoology,
} University of Alberta, Edmonton, Alberta.
A somewhat similar observation of apparent death-feigning in this species, also in the Delta area, was reported by Nero (1967), and accounts of deathfeigning behaviour in other species of frogs and toads have been reported by Dickerson (1906:71, 87), Noble (1931: 424), and Banta and Carl (1967). Nero (1967) thought such behaviour unusual in this species, and Banta and Carl (1967) referred to it as unusual in Hyla versicolor, the Gray Treefrog. Both Dickerson (1960:71) and Noble (1931:424), however, imply that deathfeigning is easy to elicit in frogs and toads.

Clearly, more observations of this behaviour and the conditions under which it occurs are needed. Several features should be noted:

(1) Size: The toad reported by Nero (op. cit.) was "about an inch long", as was that observed by me. Other reports (Dickerson op. cit.; Noble op. cit.; Sutton, 1961) refer to death-feigning behaviour as occurring particularly in young individuals.

(2) Length of time involved in feint: Noble (op. cit.) stated that the feint "usually lasts only a few minutes, but it may be prolonged over an hour if disturbing sensory impressions are avoided." All other observations cited referred to short time periods (Dickerson op. cit.; Nero op. cit.; Banta and Carl op. cit.; this note). 